\title{
The Common Hurdles of Flipped Learning Approach
}

Siti Fatimah Abd. Rahman, Melor Md Yunus, Harwati Hashim, Siti Farhani Mohd Ali

To Link this Article: http://dx.doi.org/10.6007/IJARBSS/v11-i6/10026

DOI:10.6007/IJARBSS/v11-i6/10026

Received: 05 April 2021, Revised: 08 May 2021, Accepted: 28 May 2021

Published Online: 15 June 2021

In-Text Citation: (Rahman et al., 2021)

To Cite this Article: Rahman, S. F. A., Yunus, M. M., Hashim, H., \& Ali, S. F. M. (2021). The Common Hurdles of Flipped Learning Approach. International Journal of Academic Research in Business and Social Sciences, 11(6), 717-728.

\section{Copyright: (c) 2021 The Author(s)}

Published by Human Resource Management Academic Research Society (www.hrmars.com)

This article is published under the Creative Commons Attribution (CC BY 4.0) license. Anyone may reproduce, distribute, translate and create derivative works of this article (for both commercial and non-commercial purposes), subject to full attribution to the original publication and authors. The full terms of this license may be seen at: http://creativecommons.org/licences/by/4.0/legalcode

\section{Vol. 11, No. 6, 2021, Pg. 717- 728}

Full Terms \& Conditions of access and use can be found at http://hrmars.com/index.php/pages/detail/publication-ethics 


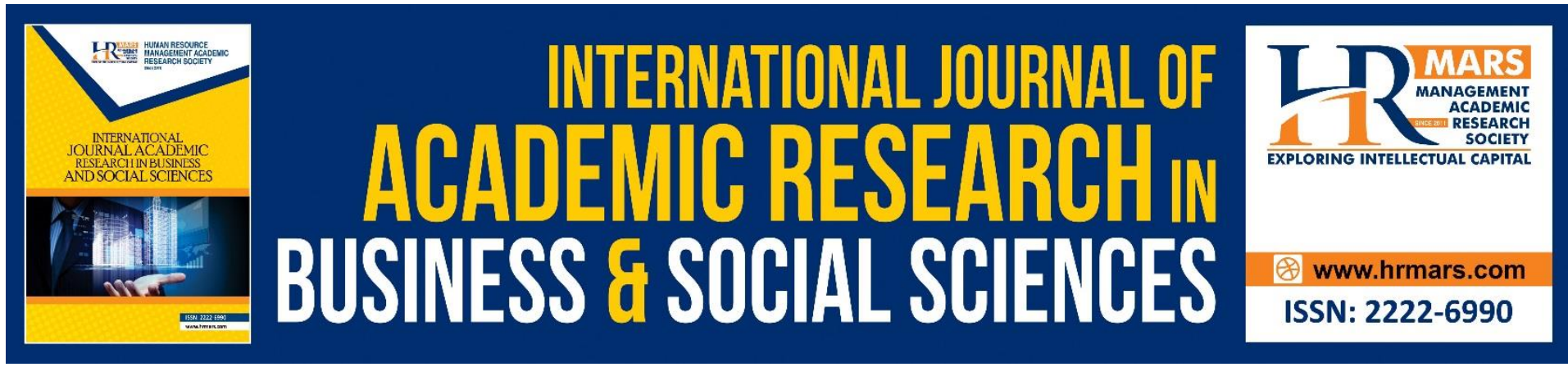

\title{
The Common Hurdles of Flipped Learning Approach
}

\section{${ }^{1}$ Siti Fatimah Abd. Rahman, ${ }^{2}$ Melor Md Yunus, ${ }^{3}$ Harwati Hashim, ${ }^{4}$ Siti Farhani Mohd Ali}

Kulliyyah of Education, International Islamic University Malaysia (IIUM), Malaysia, ${ }^{2}$ Faculty of Education, Universiti Kebangsaan Malaysia (UKM), Malaysia, ${ }^{3}$ Faculty of Education, Universiti Kebangsaan Malaysia (UKM), Malaysia, ${ }^{4}$ Academy of Language Studies, Universiti Teknologi MARA (UiTM), Malaysia

Email: sfarahman@iium.edu.my,melor@ukm.edu.my, harwati@ukm.edu.my, siti_farhani93@yahoo.com

\begin{abstract}
A bstract
This paper provides a review of the past studies related to flipped learning as well as the hurdles faced by educators in integrating the flipped learning approach. Even though flipped learning has many benefits, and it has been proven to enhance learners' achievement by a number of studies, challenges in implementing it still need to be endured by educators. The highlighted hurdles are the negative perception, the development of the digital instructions, accessibility, educator and learner's resistance, lack of learner responsibility, workloads and traditional classroom. Those hurdles might lead to educators' resistance in implementing flipped learning approach. However, educators need to come out with strategies in overcoming the issues.
\end{abstract}

Keywords: Flipped Learning, Flipped Classroom, Flipped Learning Obstacles, Challenges, Digital Instruction, Educational Technology, $21^{\text {st }}$ Century of Education

\section{Introduction}

The $21^{\text {st }}$ century of education requires the paradigm shift in teaching styles. It demands a student-centred way of learning rather than the traditional classroom where the educator is postulated to be centred of learning (Yeop, 2019). Since innovation evolves (Yunus, 2018), education has no exception. Technology-integrated teaching and learning is one of the preferred ways as it offers unlimited resources to education (Sun \& Goa, 2019). It is also a medium of delivering and receiving information between educator and learners (Zaki \& Yunus, 2015). The young learners prefer to do everything online, including learning and socializing. One of the studies on online learning shows that students are learning the elements of the English language through social media (Shazali, Shamsudin \& Yunus, 2019). Hence, the educator should consider applying flipped learning in teaching and learning as it has tremendous benefits. 
Flipped learning is one of the growing technology-integrated teaching approaches that categorised under blended learning (Rahman, Yunus, \& Hashim, 2020). It was introduced by Jonathan Bergmann and Aaron Sams in 2007 because their students could not come to class due to training and tournaments. They recorded their lectures and put it online, so the absent students could be able to watch it later (Hamdan, 2013). It became a widespread approach ever since. The purpose of this paper was to look at a number of research in flipped learning and to find out the common challenges faced by both educators and students. The challenges include all the aspects of practicality, accessibility, attitudes as well as perceptions. The study can be used by educators and stakeholders to implement flipped learning in their institutions and at the same time, they will be more aware of the challenges and any related and relevant issues can be avoided while initiating flipped learning.

\section{A Review of Flipped Learning}

The number of empirical research on the effectiveness and advantages of a flipped classroom approach is increasing. Flipped learning is proven to be promoting meaningful learning in the classroom (Embi \& Panah, 2014). Among the other perks of flipped learning as found by this research is the increment in learners' presence, classroom involvement, learning gains as well as encouraging learner perceptions (Deslauriers, Schelew \& Wieman, 2011; Pierce, 2013; Roehl, Reddy \& Shannon, 2013). An in-depth survey on the flipped classroom approach which was carried out based on prior research has been completed by Bishop \& Verleger (2013). The researchers found that most recent studies focus on exploring learners' awareness and utilizing single-group studies (Bishop \& Verleger, 2013). Based on the studies, Bishop \& Verleger found out that learners typically give encouraging perceptions, but there are also several learners who do not like the changes in pedagogy. Learners made preparations before attending the class and watched the instructional videos as assigned, although they are not required to do so (Janet, 2012). The surveyed research also utilized pre-class quizzes based on the material of the instructional video lecture. Learners tend to favour the in-class learnercentred activities in comparison to in-class lectures.

As concluded by Bishop \& Verleger (2013), this research has found that most of the studies on flipped classroom focus more on examining learners' perceptions and single-group studies. McLaughlin, Griffin, Esserman, Davidson \& Glatt (2013) has compared two pharmaceutical courses offered at two different campuses utilizing the flipped classroom approach in 2012 with the data obtained from the 2011 courses which were taught through the traditional lecture method. The results of the survey showed that learners' support for learning content before attending class has increased and higher application learning in class can be observed. Learners claimed by learning key essential content before attending class has enhanced inclass learning. Based on the qualitative findings of the research, it is proven that the flipped classroom is able to encourage learners' empowerment, development as well as engagement. There is no significant difference between the traditional format and the flipped course format. As a conclusion, learners' experiences can be improved by the flipped classroom through course design, enriched dialogue and encouraging learner's autonomy.

An experiment has been carried out by instructors at the University of British Columbia. Two experienced professors have been assigned to teach two physics courses utilizing the traditional lecture format, until the final week of the semester. During the final week, two less-experienced instructors were sent in to replace the experienced professors. One of the 
classes were taught using a flipped style, and the other class were taught using the same traditional lecture style. In the flipped classroom, learners were assigned to do readings and complete the take-home online quizzes. During the meetings in class, learners were assigned to answer questions in the peer discussion group, carry out group-learning activities and the instructor will provide immediate feedback. The study found that the experimental group in the flipped classroom showed an increment of $20 \%$ in attendance, $40 \%$ in engagement and has doubled up the learner comprehension in comparison to the control group that use the traditional lecture format (Deslauriers, Schelew, Wieman, 2011).

A study by Telley \& Scherer (2013) examined the effects of a flipped classroom approach that used learner-recorded lectures and practice testing in boosting academic performance in undergraduate psychology courses. The research implemented a hybrid model approach to the flipped classroom through the usage of pre-recorded instructor video lectures, videos of a self-explanation learner and practice testing during class sessions. "A hybrid version of the flipped classroom can be represented by allocating some of the classroom time for reviewing and practising testing instead of the common lecture delivery" (Taley \& Scherer 2013) p. 340. Other than that, the research has also defined the "enhanced flipped classroom model" as the learning strategies which focus on the usage of technology. Among the examples of technologies are including the usage of e-books, YouTube, Blackboard, whiteboard presentations for iPad, electronic flashcards in practice testing as well as the usage of selfexplanation learning techniques. The findings revealed that there was a notable difference in course performance as compared to the previous semester where the learners were being taught using the traditional lecture approach.

In 2014, Butt studied the learners' perceptions towards the flipped classroom approach during the final year of an actuarial course. Most of the responses received from the flipped classroom structure were encouraging. As the semester started, $50 \%$ of the learners believed that the structure would be helpful for them. By the end of the semester, $75 \%$ of the learners were in favour of the flipped classroom, claiming that this kind of approach helped to enhance their learning experience in comparison the traditional lecture approach (Butt, 2014). These results are coherent with the findings of Schullery, Reck \& Schullery (2011) as well as Bates \& Galloway (2012) in which the learners' positive perceptions were $68 \%$ and $80 \%$ respectively. The nature of the existing data is reflected in this short survey of the research on the flipped classroom approach. Up until today, studies tend to focus on examining learners' perceptions while small single-group quantitative studies investigating academic performance as well as the learning gains. Researchers concluded their academic writings by suggesting that additional studies can be carried out to further investigate on larger data sample and instructional methods and approaches to boost the outcomes of learner-learning. While some suggestions for practices and strategies have been suggested by several studies, there is still no explanations on factors that affecting lecturers' attitude towards flipped learning while transitioning to the flipped classroom approach. Due to that, this study needs to be carried out at a different perspective, which is lecturers.

\section{The Hurdles}

\section{Negative Perception}

Lecturers or educators' attitude towards technology can affect learners' performance in the learning process (Bruess, 2003). It is common to deal with the negative perception of the effectiveness of a new pedagogical approach. The advantages of active learning activities 
including discussion or collaborative learning approaches that substitute lecture time are among the educators' initial concerns (Fagen et al., 2002). Data on an empirical study that highlights the learners' learning gains, for example through the comparison of achievement between classrooms that use the flipped approach and the ones that do not can help to subside the perception. According to Weimer (2013), proof and documentation which support the effects of the approaches tend to persuade the colleagues and administrators rather than preaching them. When the sceptics have the opportunity to experience learning in a flipped classroom environment, they will be able to study the encouraging aspects which are demonstrated through learners' perceptions as well as the learning space itself. The critics worry that it may rely too much on homework and the usage of technology. However, Bennett (2012) claims articles sometimes do not mention that homework or video is merely a part of a more extensive process; hence the flipped classroom approach is not wholly dependent on them. As defined by Bennett (2012) in the flipped classroom, the learning roles will be reversed and learners are expected to determine their own learning pace. According to Weimer (2013), learning can be promoted through teaching "by facilitating the acquisition of knowledge" (p. 9). Learner-centred instruction does not merely focus on the actual teachinglearning process. It is also related to other features of the process, from curriculum development to the relationship of the educator and the learner (Zygmont \& Shaefer, 2005).

\section{Digital Instruction Development}

In developing classroom lectures through the usage of videos or podcast, the instructor may face hurdles in the flipped classroom such as time-constraint and lack of energy (Herreid \& Schiller, 2013). Though the differences between the flipped classroom and digital instruction, most of the flipped classroom utilize this approach to allocate more class time to promote active learning engagement. To ease the flipping process of the classroom and minimize the efforts needed in creating videos, the instructor can access various online databases of instructional videos such as Khan Academy and similar resources sites for classroom use (Bergmann \& Sams, 2012; Khan, 2011). In implementing the assessments for mastery learning, or find suggestions for classroom activities and peer instruction concept tests, one can access the additional online database sources (Fagen, Crouch \& Mazur, 2002). There are a few additional challenges that are being faced by the faculty as they shift to a flipped classroom model as discussed by Aronson, Arfstrom \& Tam (2013). Several concerns on initial course redesign have been identified by their research. The faculty needs additional time and effort to transform their courses into a flipped model. The faculty may be teaching many courses, at different locations and may have other formal duties that may hinder the required initial effort.

In using a flipped model, Seaboyer (2013) and some of his colleagues have redesigned their courses to enhance reading effectiveness. The case study found that although they have to invest some time, it pays off as they have lighter future workload and learners tend to experience more in-depth learning. Faculties can work hand-in-hand with each other in flipping a course by sharing resources or utilizing co-teaching practices (Seaboyer, 2013). Based on a supporting study, to create a more professional experience and boost pedagogical practices for instructions, collaboration efforts in designing instructions are required (Brown, Eaton, Jacobsen et al. 2013). Some universities such as the University of Washington and Vanderbilt University provide other instructional design resources through resource centres to help instructors seeking help in teaching and learning (Aronson et al., 2013). 


\section{Accessibility}

A digital boundary of computer and Internet accessibility is still there for the $21^{\text {st }}$-century learners, although it is slowly deteriorating. Ever since 1984, data on Americans ownership of computers and Internet usage has been collected from time to time by the United States Census Bureau. 8.2 per cent of Americans were reported to have a computer in their households in 1984 (File, 2013). In 2003, the number was increased to 61.8 per cent, and the latest report in 2012 claimed that computers were owned in 78.9 per cent of American households (United State Census Bureau, 2012). The similar increment can be observed for household Internet used, with 71.7 per cent of households were reported to be accessing Internet in 2011, which has been increased from 18 per cent in 1997 (the first year when the Census Bureau began collecting data about Internet use) and 54.7 percent in 2003 (the first year that observed more than 50 per cent of households were reported to be accessing the Internet) (File, 2013). The 2012 report also featured the variances of usage based on several characteristics including age, household income and level of education. 82.8 and 82.0 per cent of individuals aged 18 and 34 years old respectively were reported to have the highest percentages when it came to home computer ownership and Internet usage (File, 2013). The study also showed that computer ownership and Internet usages have relations to the household income. The report exhibited that merely 56.7 per cent households with an income of less than $\$ 25,000$ have a home computer. Not only that, but educational attainment also has a relationship to computer ownership and Internet use. A household with highly educated individuals tends to have a higher percentage of computer ownership and Internet usage (File, 2013). The census report also collected data on the usage of smartphone, in which "48 per cent of individuals aged 15 years and above" were reported to use it (File, 2013) p. 11.

Although the number of computer ownership, Internet access and smartphone usage is escalating; educators still need to come with alternative options in terms of accessibility which will be able to suit all learners. In promoting digital equity, CDs, DVDs or institutionprovided devices including iPods or recycled smartphones can be distributed amongst learners who may have issues with Internet accessibility to watch the videos or podcasts at home (Bull, Ferster \& Kjellstrom, 2012). Hamdan et al. (2013) also claimed that in creating equal learning environments, there are a variety of possible ways which can be taken to deliver instruction digitally. In reviewing the course material, learners can be equipped with memory devices that have video content. Other than that, digital content can also be made available to be accessed from the growing number of smartphone devices. In accessing the material, learners are suggested to use iPod or iPad devices with a free iTunes account so that they can access the material. Finally, for those unfortunate learners who do not have home accessibility, schools can team up with local libraries and community centres in providing easy accessibility of material to them (November \& Mull, 2012).

\section{Learner's Hesitance}

When it comes to pedagogical changes in the classroom, it is common to observe resistance among the learners themselves. They have grown accustomed to the traditional lecture methods that they tend to forgo adapting to a new innovative style (Aronson, Arfstrom \& Tam, 2013). Now that the pedagogical approach has changed, learners are required to prepare knowledge before to attending class as they are now responsible for their learning. The flipped classroom will not let learners to just passively "sit and get" information as they 
have to participate actively and achieve the objectives. Learners and educators will work hand-in-hand in constructing a conducive learning environment in the learner-centred approaches. Learners have to be responsible for their learning as the educator's role has shifted to a facilitator (Zygmont \& Schaefer, 2005).

Furthermore, the learners will probably defy the necessary "intellectual effort" in achieving the learning goals in the early stage (Smith \& Cardaciotto, 2011). According to Weimer (2013), several reasons contribute to the learner resistance towards the flipped class model. 1) The learner is required to do more work than they are starting to feel as though they are doing the educator's part. 2) Learner-centred approaches push the learners far from their familiar comfort zone as they are being introduced to a new learning process. They find critical thinking to be quite challenging and would instead be told on what needs to be done. Learners are afraid to rely on themselves, rather than the experts as they doubt their ability to deliver what they have been asked to do. 3) The fact that the learners are being taken to a new level of learners' responsibility, the learner-centred approaches can make them feel lost. "Classrooms where educators make all the decisions are safe, simpler place" (p. 203). Although the learner-centred approaches promote intellectual development, the feeling of loss of certainty may be demonstrated as resistance. Identical learner resistance towards the classroom structure and task orientation have been documented by Strayer (2012). Learners need to "learn at the rate which the classroom is going rather than letting it slide and cramming at the last moment" (Aronson, Arfstrom \& Tam, 2013, p. 4). Bergmann and Sams (2012) claimed that deep learning could occur once the learners learn to value learning instead of "playing school". Learners' awareness of their learning processes can be promoted by the structural differences of the flipped classroom (Roehl, et al., 2013). In Malaysia, minor problems encountered in using flipped learning are the quality of the videos prepared by educators, videos that contain delicate accents and background noise in some videos (Roehl, et al., 2013). A study by Zainuddin \& Attaran also found out that flipped learning gives a problem to part-time learners as they only have Saturday and Sunday to learn and they are working the whole weekdays. Thus, they do not have ample time to study outside the classroom as suggested in the flipped learning approach.

\section{Educator's Hesitance}

As the educator shifts from being an expert in the traditional educator-centred pedagogy to being a novice in the new learner-centred pedagogy, the educator tends to manifest fear and anxiety among themselves. This is considered an attitude towards new technology. According to Aaronsohn (1996), even the experienced educators may face difficulties in facing the changes as they have to operate differently to what they are accustomed to in the past. Some educators want to avoid stress from worrying about being uncertainty in front of their learners and colleagues. Although the educators may be supportive of the effectiveness of a learner-centred approach, they may "face pressure to question their skills, and feel drawn to behave in ways that are consistent with the culture of the school" (Aaronsohn, 1996) p. 12.

A transition into a learner-centred flipped classroom approach which promotes autonomy in learning may cause worry and stress among the educators (Shumsky \& Shumsky, 1968). According to Weimer (2013), teaching using the learner-centred approach is tougher for educators because it becomes less scripted and they are moved into an unfamiliar instructional domain. As the educator may need to cope with the possible diminishing amount 
of content, alteration of learner power in the processes of decision and assessment and shrinkage in rules and requirements, the educators may feel uncertainty and this will manifest as educator resistance. Apart from self-resistance, "educators may be insecure about trusting learners to rise to the challenge" (Zygmont \& Schaefer, 2005) p. 137. Educators need to allow the learners to assess their learning activities and must be able to give feedback on specific aspects of the learners' reflection. Roehl et al. (2013) believe that this feedback cycle is essential in assessing learners' learning and some educators may find it challenging for them to make such adjustments.

\section{Lack of Learner Responsibility}

To successfully construct a learning environment, learners need to be responsible for their learning (Cubukcu, 2012). Learners who have not watched the videos before attending the class indicates a lack of preparation. Herreid \& Schiller (2013) overcome the issue by giving quizzes or homework which can be answered by watching the videos. The learner will feel the need to view the material to be able to answer such in-class quizzes and other forms of formative assessment of video content (Fagen et al., 2002). Other than that, the learners can also be asked to submit reflections, questions and concerns before attending the class (Fagen et al., 2002). Bergmann \& Sams (2012) suggests that two computers can be provided at the back of the classroom so that the learners can view the videos during the class. However, unprepared learners will learn that they are wasting the collaborative class time with educator presence so that they can work on assignments. "Regularly presenting classaveraged data on learner performance also shows learners that the method is helping them and thus may also motivate learners" (Fagen et al., 2002) p. 208.

\section{Educator Workload and Training Development}

Dewey (1916) once questioned, "Why is it, even though teaching by pouring in and learning by passive absorption, are universally condemned, that they are still so entrenched in practice?" (p. 23). Although the question was asked by Dewey nearly over ten decades ago, it is still relevant in today's classrooms. Lecturers or educators need support in technical and also development issues. Most of the time changes in pedagogy call for additional educator preparation and some additional developmental training if the educator is still lacking in skills and not comfortable with the changes. Like the United States, international educational reform has pushed for a change from the traditional lecture approach and rote learning to learner-centred teaching approaches including collaborative work and project-based inquiries (Wang, 2011). Albeit these efforts, faculty tends to resist the implementation of learner-centred learning approaches. An ethnographic study carried out by Wang (2011) identified the factors that contribute to the educator's resistance to change. The findings showed that educators can control the teaching pace in the traditional lecture approach, whereas the learner-centred approach consumes more time and time for task completion is unpredictable. Not only that, but the educator also lacks knowledge of how to create and implement classroom instruction.

Support provided by the institution for the development of faculty in blended learning instructional methods has been investigated by Eunjoo \& Suhong (2009). Since blended learning uses both in-class and online material to support learning, it tends to be associated with the flipped classroom approach. The findings showed that the workload assigned by the faculty and lack of motivation and enthusiasm are the biggest challenges in constructing 
blended learning instruction. In improving faculty motivation, institutions need to alter their support system so that faculty evaluation systems and promotional policies can be aligned to support the increment in workload and any risk in blended learning instruction. A support system, which offers direct encouraging feedback, may "create well-integrated, effective educators by helping them feel positive enough about themselves to devote their time and energy to the need satisfaction of others" (Aaronsohn, 1996).

\section{Traditional Classroom}

The implementation of the flipped classroom does not require the traditional lecture method to be eliminated. Some lessons still require the traditional lecture approach to enhance the learning outcomes. Covill (2011) carried out a survey of 51 learners to learn about their views on the traditional lecture method. Results showed that learners do not have negative perceptions of the traditional method, contrary to what a majority of educators believe. Through traditional lecture approaches, learners have been reported to demonstrate high levels of learning and engagement in independent thinking and problem-solving concepts. Even so, this study does not have quantitative data to support the coherence of the perceptions of learners with performance and achievement results. Two interpretations of the learners' encouraging views towards lecture-based learning have been suggested by Covill (2011). First, the view may be contrary to the reality of the objectives and they are probably demonstrating learning weaknesses with such a method of content delivery. A second interpretation is that the learners' perceptions are authentic and learners demonstrate longlasting content knowledge.

Additionally, Johnson (2011) suggests that in improving the traditional lecture, the fundamentals of the flipped classroom model can be utilized through pedagogies that combine both active learning and lecture approaches. Malik (2011) found that learners' level of motivation has been escalated, they also have improved their communication skills and demonstrated significant levels of achievement through the implementation of active lecturing pedagogies. This technique proved that the traditional lecture technique is valid and it is a valuable pedagogy if it is used correctly used in the classroom.

\section{Conclusions}

Since the internet and technology have become part of our life, it also has penetrated to many aspects of life, especially in education (Divayan, 2019; Zhang, Wu, Qian \& Plv, 2019). As part of teaching approach and being integrated with technology, flipped learning offers more enormous advantages compared to the traditional approach such as meaningful learning, better course materials, and better interaction between learner and educator. It also supports autonomous learning (Zhang, 2019). Since flipped learning comes hand in hand with technology, and technology evolves, it provides better instructions and strategies to educators. Conversely, this approach still has its hurdles and challenges in implementing it, especially the use of technology. Therefore, by weighing the benefits of flipped learning, educators should come out with creative ways in overcoming the hurdles to integrate this approach in the classroom successfully. 


\section{Acknowledgment}

Competing Interests: The authors declare that they have no competing interests. Acknowledgement: All authors contributed equally to the conception and design of the study. Funding: This study received no specific financial support.

\section{References}

Aaronsohn, E. (1996). Going against the grain: Supporting the student-centered teacher. Thousand Oaks, Calif: Corwin Press.

Aronson, N., Arfstrom, K., \& Tam, K. (2013). Flipped Learning in Higher Education. Pearson. Retrieved from http://www.flippedlearning.org/cms/lib07/VA01923112/Centricity/Domain/41/High erEd WhitePaper\%20FINAL.pdf

Bates, S., \& Galloway, R. (2012). The Inverted Classroom in a Large Enrollment Introductory Physics Course: A Case Study. The Higher Education Academy. Retrieved from http://www.heacademy.ac.uk/assets/documents/stemconference/PhysicalSciences/Simon_Bates_Ross_Galloway.pdf

Bennett, B. (2012). Moving the Flipped Class. Retrieved from http://www.brianbennett.org/blog/moving-the-flipped-class

Bergmann, J., and Sams, A. (2012). Flip Your Classroom: Reach Every Student In Every Class Every Day. Washington, DC: ISTE; and Alexandria, VA: ASCD

Bishop, J. L., \& Verleger, M. A. (2013). The Flipped Classroom: A Survey of the Research. Paper Presented At The 2013 American Society For Engineering Education Conference.

Brown, B., Eaton, S. E., Jacobsen, D. M., Roy, S., \& Friesen, S. (2013). Instructional Design Collaboration: A Professional Learning and Growth Experience. Journal of Online Learning \& Teaching, 9(3), 439-452.

Bruess, L. (2003). University ESL Instructors' Perceptions and Use of Computer Technology in Teaching. Dissertation Abstracts International. 64 (05). 1509A. (UMI No. 3092896).

Bull, G., Ferster, B., \& Kjellstrom, W. (2012). Inventing the flipped classroom. Learning and Leading with Technology, 40(1), 10-12.

Butt, A. (2014). Student Views On The Use Of A Flipped Classroom Approach: Evidence From Australia. Business Education \& Accreditations, 6 (1), 33-43.

Covill, A. (2011). College Students' Perceptions of the Traditional Lecture Method. College Student Journal, 45(1) 92-101.

Cubukcu, Z. (2012). Educators' Evaluation of Student-Centered Learning Environments. Education, 133(1) 49-55.

Deslauriers, L., Schelew, E., \& Wieman, C. (2011). Improved learning in a large-enrollment physics class. Science Magazine, 332 (6031), 862-864.

Dewey, J. (1916). Democracy and Education: An Introduction to the Philosophy of Education / John Dewey. New York, NY: The Macmillan Company.

Embi, M. A., and Panah, E. (2014). Overview of Flipped Learning. Blended \& Flipped Learning: Case Studies in Malaysian HEls

Eunjoo, O., \& Suhong, P. (2009). How Are Universities Involved In Blended Instruction? Journal of Educational Technology \& Society, 12(3), 327-342.

Fagen, A. P., Crouch, C. H., \& Mazur, E. (2002). Peer instruction: Results from a range of classrooms. The Physics Teacher, 40(4), 206-209. 
Fagen, A. P., Crouch, C. H., \& Mazur, E. (2002). Peer Instruction: Results from a Range Of Classrooms. The Physics Teacher, 40(4), 206-209.

File, T. (2013). Computer and Internet Use in the United States. Current Population Survey Reports, 20-568. U.S. Census Bureau, Washington, DC.

Hamdan, N., McKnight, P., McKnight, K., \& Arfstrom, K. M. (2013). The Flipped Learning Model: A White Paper Based On The Literature Review Titled A Review Of Flipped Learning. Retrieved from http://www.flippedlearning.org/cms/lib07/VA01923112/Centricity/Domain/41/Whit ePaper_FlippedLearning.pdf

Herreid, C., \& Schiller, N. A. (2013). Case Studies and the Flipped Classroom. Journal of College Science Teaching, 42(5), 62-66.

Janet, L., DeGrazia, John, L., Falconer, G. N., and Medlin, w. (2012). Incorporating screencasts into chemical engineering courses. In Proceedings ofthe ASEE Annual Conference \& Exposition, 2012.

Johnson, P. (2011). Actively Pursuing Knowledge in the College Classroom. Journal of College Teaching \& Learning, 8(6), 17-30.

Khan, S. (2011). Salman Khan: Let's use video to reinvent education | Video on TED.com. TED: Ideas worth spreading. Retrieved from http://www.ted.com/talks/salman_khan_let_s_use_video_to_reinvent_education.h tml

Malik, S. (2011). Active lecturing: An Effective Pedagogic Approach. International Journal Of Academic Research, 3(2), 963-967.

McLaughlin, J. E., Griffin, L. M., Esserman, D. A., Davidson, C. A., \& Glatt, D. M. (2013). Pharmacy student engagement, performance, and perception in a flipped satellite classroom. American Journal of Pharmaceutical Education, 77(9), 196.

November, A., \& Mull, B. (2012). Flipped Learning: A Response to Five Common Criticisms. November Learning. Retrieved from http://novemberlearning.com/educationalresources- for-educators/teaching-and-learning-articles/flipped-learning-a-responseto-five- common-criticisms-article/

Pierce, R. (2013). Student Performance In A Flipped Class Module. In R. Mcbride \& M. Searson (Eds.), Proceedings Of Society For Information Technology \& Teacher Education International Conference 2013 (Pp.942-954). Chesapeake, VA: AACE.

Rahman, S. F. A., Yunus, M. M., \& Hashim, H. (2020). The Uniqueness of Flipped Learning Approach. International Journal of Education and Practice, 8(3), 394-404. https://doi.org/10.18488/journal.61.2020.83.394.404

Roehl, A., Reddy, S., \& Shannon, G. (2013). The flipped classroom: An opportunity to engage millennial students through active learning strategies. Journal of Family \& Consumer Sciences, 105(2), 44-49.

Schullery, N. M., Reck, R. F., \& Schullery, S. E. (2011). Toward Solving The High Enrollment, Low Engagement Dilemma: A Case Study In Introductory Business. International Journal Of Business, Humanities And Technology, 1(2), 1-9.

Seaboyer, J. (2013). The Role of Technology-Assisted Assessment in Fostering Critical Reading in Undergraduate Literary Studies. International Computer Assisted Assessment Conference. UK: Computer Assisted Assessment.

Shazali, S. S., Shamsudin, Z. H., \& Yunus, M. M. (2019). Instagram: A Platform to Develop Student's Writing Ability. International Journal of Academic Research in Business and Social Sciences, 9(1), 88-98. 
Shumsky, A., \& Shumsky, A. (1968). In Search Of Teaching Style. New York: AppletonCentury- Crofts.

Smith, C., \& Cardaciotto, L. (2011). Is Active Learning Like Broccoli? Student Perceptions Of Active Learning In Large Lecture Classes. Journal Of The Scholarship Of Teaching \& Learning, 11(1), 53-61

Strayer, J. (2012). How Learning In An Inverted Classroom Influences Cooperation, Innovation \& Task Orientation. Learning Environments Research. 15(2), 171-193.

Talley, C. P., \& Scherer, S. (2013). The enhanced flipped classroom: Increasing academic performance with student-recorded lectures and practice testing in a "Flipped" STEM course. Journal of Negro Education, 82(3), 339-347.

United States Census Bureau. (2012). Measuring America: Computer \& Internet Trends in America. Retrieved from https://www.census.gov/hhes/computer/files/2012/computer_use_infographic_fin al.pdf

Wang, D. (2011). The Dilemma Of Time: Student-Centered Teaching In The Rural Classroom In China. Teaching And Teacher Education, 27(1), 157-164.

Weimer, M. (2013). Learner-centered teaching: five key changes to practice. San Francisco, CA: Jossey-Bass.

Yeop, M. A. (2019). Implementation of ICT Policy (Blended Learning Approach ): Investigating factors of Behavioural Intention and Use Behaviour 12(1), 767-782.

Yunus, M. M. (2018). Innovation in Education and Language Learning in 21St Century. Journal of Sustainable Development Education and Research, 2(1), 33. https://doi.org/10.17509/jsder.v2i1.12355

Zainuddin, Z., \& Attaran, M. (2016). Malaysian students' perceptions of flipped classroom: a case study. Innovations in Education and Teaching International, 53(6), 660-670. https://doi.org/10.1080/14703297.2015.1102079

Zaki, A. A., \& Yunus, M. (2015). Potential of Mobile Learning in Teaching of ESL Academic Writing. English Language Teaching;, 8(6), 11-19. https://doi.org/10.5539/elt.v8n6p11

Zygmont, D., \& Schaefer, K. (2005). Making the transition from teacher-centered to student- centered instruction: a journey taken by two educators. Annual Review of Nursing Education, 3, 125-142. 